\title{
Wagneropteris minima, a new medullosalean pteridosperm from the middle Westphalian (Middle Pennsylvanian) of the Peñarroya-Belmez-Espiel Coalfield (Córdoba province, SW Spain)
}

\author{
Carmen ÁLVAREZ-VÁZQUEZ ${ }^{*}$ \& Christopher J. CLEAL ${ }^{2}$
}

\author{
${ }^{1}$ Centro Paleobotánico, Real Jardín Botánico de Córdoba, Avenida de Linneo, s/n, 14004 Córdoba, Spain; paleo.calvarez@ \\ jardinbotanicodecordoba.com \\ ${ }^{2}$ Department of Natural Sciences, National Museum Wales, Cathays Park, Cardiff CF10 3NP, United Kingdom; chris.cleal@ \\ museumwales.ac.uk \\ * Corresponding author
}

Álvarez-Vázquez, C. \& Cleal, C.J. 2016. Wagneropteris minima, a new medullosalean pteridosperm from the middle Westphalian (Middle Pennsylvanian) of the Peñarroya-Belmez-Espiel Coalfield (Córdoba province, SW Spain). [Wagneropteris minima, nueva pteridosperma medulosal del Westfaliense medio (Pensilvánico Medio) de la cuenca minera de Peñarroya-Belmez-Espiel (provincia de Córdoba, SO España)]. Spanish Journal of Palaeontology, 31 (1), 5-24.

\begin{abstract}
A new taxon, Wagneropteris minima gen. and sp. nov., is described from lower Bolsovian strata of the PeñarroyaBelmez-Espiel Coalfield (Córdoba province, SW Spain). Most important for a generic diagnosis is the presence of small pinnae on the antepenultimate rachis and intercalated pinnules on the penultimate rachis and imparipinnate last order pinnae. It probably has affinities with the Callipteridium-complex of medullosalean fronds, belonging to the fossil-family Cyclopteridaceae.
\end{abstract}

Keywords. Wagneropteris minima gen. and sp. nov., Medullosales, middle Westphalian, Peñarroya-Belmez-Espiel Coalfield, SW Spain.

\section{RESUMEN}

Se describe un nuevo taxon, Wagneropteris minima gen. y sp. nov., del Bolsoviense inferior de la cuenca minera de Peñarroya-Belmez-Espiel (provincia de Córdoba, SO España). La característica más importante para la diagnosis es la presencia conjunta de pinnas de último orden imparipinnadas y pequeñas pinnas unidas a los raquises de antepenúltimo orden, y de pínulas en los raquises de penúltimo orden. Se analiza su posible relación con otras Medullosales del grupo Callipteridium y su pertenencia a la familia Cyclopteridaceae.

Palabras clave. Wagneropteris minima gen. y sp. nov., Medullosales, Westfaliense medio, cuenca minera PeñarroyaBelmez-Espiel, SO España. 


\section{INTRODUCTION}

Medullosalean foliage are among the most commonly found plant remains in the Pennsylvanian terrestrial deposits of the palaeoequatorial belt. Although knowledge of their anatomy and associated reproductive structures remains very incomplete (Stidd, 1981; DiMichele et al., 2006), the fronds were morphologically complex structures (e.g., Laveine, 1997), often with well-preserved cuticles revealing anatomical anatomy (Cleal \& Shute, 2012). This has provided a large range of characters on which a robust taxonomy has been established (e.g., Cleal \& Shute, 1995, 2003), which in turn has facilitated their extensive use for biostratigraphy (e.g., Dix, 1934; Wagner, 1984) and palaeobiogeography (Cleal, 2008) of the Pennsylvanian terrestrial deposits.

Because of the extensive use to which these fossils have been put, there is a vast literature dating back over two centuries recording their distribution and taxonomy. It is rare, therefore, for new species still to be discovered and even rarer for a distinctive new fossil-genus to be found. The present paper reports on just such a discovery of a new fossil-genus of medullosalean frond, from the lower to middle Westphalian of the Peñarroya-Belmez-Espiel Coalfield (Córdoba, SW Spain). Specimens of this species were first recorded in an internal report for the Empresa Nacional Adaro de Investigaciones Mineras (ENADIMSA, 1977), and listed in Wagner (1983a), Wagner et al. (1983) and Wagner \& Álvarez-Vázquez (2010) where the nomen nudum Neuropteris minima was introduced. The only published figuration of the species until now has been provided by Wagner (2001, fig. 57), although a detailed description and figuration was given in an unpublished doctoral thesis by Álvarez-Vázquez (1995).

Although the pinnule morphology resembles that of an imparipinnate neuropteroid, the frond architecture is quite different and characterised, above all, by the presence of intercalary pinnules on the penultimate rachises and imparipinnate last order pinnae; for this reason we propose that this represents a new fossil-genus.

\section{MATERIALS}

Nearly three hundred specimens of this new taxon, preserved as adpressions, have been available for examination. The available specimens were all collected in the southeastern part of the Peñarroya-Belmez-Espiel Coalfield (Fig. 1), first of all from boreholes and exploratory trenches made in the 1970s by Empresa Nacional Adaro de Investigaciones Mineras (ENADIMSA), and later (1980s and 1990s) by the Geology Department of the Empresa Nacional Carbonifera del Sur, S.A. (ENCASUR). This collection was expanded in 1995 from the Corta Candelaria, an opencast mine operated by ENCASUR, near the small village of Espiel, Córdoba province, and between 2003 to 2012 by sampling in the La Ballesta opencast mine, at c. $5 \mathrm{~km}$ ESE of Espiel (see Fig. 1). These two opencast sites yielded the larger and most complete specimens.

\section{GEOLOGICAL SETTING}

The Peñarroya-Belmez-Espiel Coalfield occurs in a narrow NW-SE striking strip, in the northwestern part of Córdoba province, SW Spain (Fig. 1). Its width may never have exceeded $3 \mathrm{~km}$, whereas its length went beyond its present outcrop of $50 \mathrm{~km}$; the outcrop is covered by Cenozoic strata to the NW, and it is limited to the SE by a steeply angled thrust fault.

The coalfield corresponds to the Peñarroya Basin with a recorded history extending from late Langsettian to early Bolsovian times. It was generated alongside a major intracontinental strike-slip fault comparable to the present-day San Andreas Fault in California (Wagner, 1999, 2004, 2013). This fault was active in Pennsylvanian times, provoking subsidence of an adjacent passive plate segment which subsided to accommodate a sedimentary basin with sub-basins corresponding to different episodes of movement of the active plate. A lateral displacement of c. $150 \mathrm{~km}$ has been deduced (Wagner, 2013), affecting the metamorphic basement rocks (up to and including gneiss attributed to Precambrian-Ordovician - see Apalategui et al., 1985) with Mississippian sedimentary cover of the active plate, which moved SE-wards and now forms the SW border of the Peñarroya Basin.

Sub-basins have been dated as late Langsettian/early Duckmantian and (late Duckmantian?) early Bolsovian on megafloral associations (Álvarez-Vázquez, 1995, 1999; Wagner \& Álvarez-Vázquez, 2010; new data). There is evidence of non-marine faunas, and no evidence of any marine connection, even though there is no reason why this would not have existed. Stratigraphic dating relies on fossil floras and is expressed with reference to the West European regional chronostratigraphy. There is no uncontroversial translation into the global chronostratigraphy based, essentially, on marine faunal zonations (compare Wagner \& Winkler Prins, 2016).

A full documentation of these well-sampled floras is still an ongoing process, but so far 130 taxa have been found in the two consecutive sub-basins. The total flora is based on the analysis of c. 22,000 samples with a total of some 50,000 plant fragments. This is the most complete record of a lower to middle Westphalian flora in the Iberian Peninsula. Although containing a relatively large number of extrabasinal taxa, albeit as rare elements, the flora is 


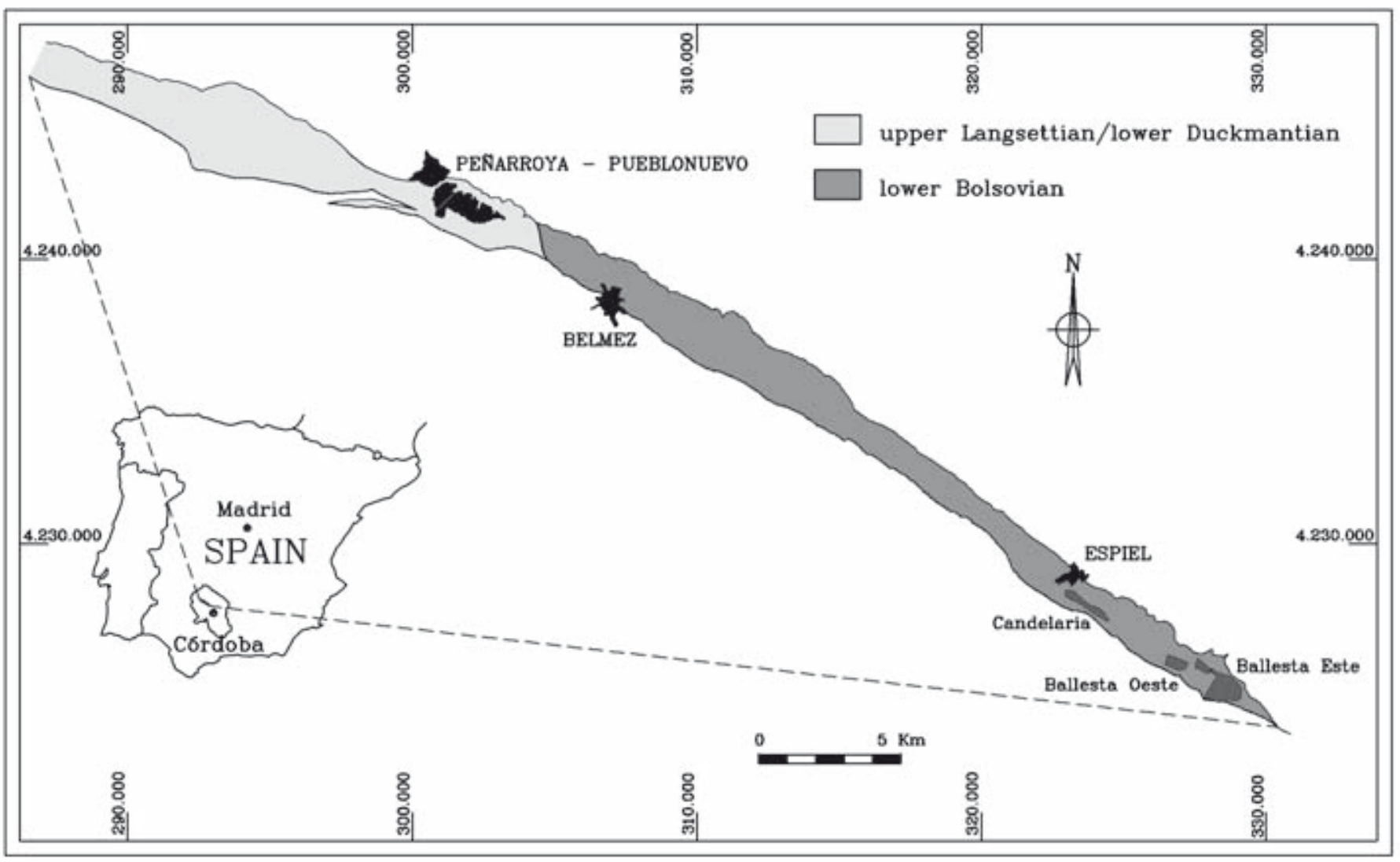

Figure 1. Sketch map of the Peñarroya-Belmez-Espiel Coalfield showing the position of the two sub-basins and location of the opencast sites.

broadly comparable with that of the classical areas of the Paralic Coal Belt in northern Europe, from South Wales through SE England and northern France through Belgium and the Netherlands into the Ruhr District of western Germany. Whereas the fern, lycopsid and sphenopsid species contents are exactly the same as in northern Europe, the Peñarroya-Belmez-Espiel Coalfield contains abundant but less diverse pteridosperms, with only five neuropterid species recognised, viz. the new one described here, Laveineopteris tenuifolia (Schlotheim ex Sternberg) Cleal, Shute \& Zodrow, Neuropteris guadiatensis Wagner emend. Álvarez-Vázquez, Neuropteris obliqua (Brongniart) Zeiller and Neuralethopteris schlehanii (Stur) Cremer.

\section{SYSTEMATIC PALAEONTOLOGY}

Class CYCADOPSIDA Brongniart, 1843

Order MEDULLOSALES Corsin, 1960

Family (?) Cyclopteridaceae Laveine ex Cleal \& Shute, 2003

Genus Wagneropteris gen. nov.

Type species Wagneropteris minima sp. nov.
Derivatio nominis. Named after Robert $\mathrm{H}$. Wagner, in recognition of his contribution to Carboniferous palaeobotany and stratigraphy, and Spanish Carboniferous geology in particular.

Diagnosis. At least tripinnate fronds, with subperpendicularly inserted pinnae characterised by intercalary pinnules on penultimate rachises and imparinnate last order pinnae. Pinnules small, ovoid to subrectangular, commonly attached by a short, broad stalk. First anadromous and catadromous pinnules of last order pinnae of more reduced size, allowing space for intercalary pinnules on the penultimate rachis; anadromous pinnules orbicular; catadromous ovoid and similar to the standard laterals, but shorter, with half their length.

Wagneropteris minima gen. and sp. nov.

(Figs 2a-8)

?1970 Neuropteris parvifolia; Ortuño, p. 1280 (cited by Ortuño in the area of Espiel; it is a small-pinnuled species that resembles Wagneropteris minima in size and pinnule shape - see Comparisons).

v p 1983a Neuropteris sp. nov. (2 species); Wagner, p. 157 (one of these species has been described as Neuropteris 
guadiatensis by Wagner 1983b, and the other is the new one described here).

v 1983 Neuropteris minima; Wagner et al., p. 56 (nomen nudum).

v 1995 Neuropteris sp. nov.; Álvarez-Vázquez, p. 4648, lám. 9, figs 1-2a, figs 3-3b (here Fig. 2a), fig. 4; lám. 10, fig. 1 (here Fig. 3a), figs 2-2a (here Figs 3b-3d).

v 1999 Neuropteris? sp. nov.; Álvarez-Vázquez, p. 43, Figs 2, 4 (name only).

v 2001 Neuropteris minima; Wagner, p. 95, fig. 57 (nomen nudum - here as Fig. 4a).

v 2010 "Neuropteris" minima (nomen nudum); Wagner \& Álvarez-Vázquez, p. 266.

N.B. System of annotations follows that of Cleal et al. (1996 - simplified): v vide: the authors have seen the specimen(s); ?: references to doubtful specimens due to poor illustration or not illustrated; $\mathrm{p}$ pars: only part of the published specimens belong to the species.

Derivatio nominis. After the Latin minimus $=$ the smallest.

Material and preservation. A total of 289 pieces from 40 localities in the southeastern part (youngest subbasin) of the coalfield, including 12 pinna fragments of the antepenultimate order and 102 pinna fragments of the penultimate order; as well as more than two hundred of more or less fragmentary last order pinnae. Specimens are preserved as adpressions on medium to coarse siltstones and fine sandstones. Specimens only required mechanical preparation with needles; all were photographed using natural light.

Holotype. The penultimate order pinna fragment from locality 4830 illustrated on Figures $3 b-3 d$ (Catalogue $n^{\circ}$ PBE01989).

Paratypes. Other specimens from the same locality: PBE01990, PBE01991 and PBE01992 (Fig. 3a).

Type locality. ZE-1, exploratory trench $500 \mathrm{~m} \mathrm{SE}$ Espiel, province Córdoba, SW Spain (see Fig. 9).

Age. Early Bolsovian (although late Duckmantian cannot be excluded).

Repository. All specimens are stored in the collections of Centro Paleobotánico, Real Jardín Botánico de Córdoba, Spain, where they are identified by locality numbers and a catalogue number preceded by PBE.

Diagnosis. Pinnules small, ovoid to subrectangular, commonly attached by a short, broad stalk; base cordate at both acroscopic and basiscopic sides in the larger pinnules; high in the pinnae of penultimate and ultimate orders, the pinnules become partially attached to the rachis. First anadromous and catadromous pinnules of last order pinnae of more reduced size, allowing space for intercalary pinnules on the penultimate rachis. Anadromous pinnules orbicular; catadromous ovoid and similar to the standard laterals, but shorter, with half their length. Midrib prominent in the lower half of larger pinnules and less well marked in the smaller; lateral veins arise from the midrib at a narrow angle to reach the margins nearly perpendicularly and bifurcating up to three times.

Description. Frond at least tripinnate (Figs 5a, 6c, 7 ), with perpendicularly inserted penultimate pinnae characterised by small pinnules. Antepenultimate pinnae always incomplete, at least $190 \mathrm{~mm}$ long and $160 \mathrm{~mm}$ width. Medial parts with penultimate pinnae inserted at approximate right angles. Terminal of what appears to be an antepenultimate pinna with apical angle of c. $40^{\circ}$ (Fig. 8) and lateral pinnae well-spaced, inserted at a wide angle (c. $80-90^{\circ}$ ). Antepenultimate rachis up to $13 \mathrm{~mm}$ wide, straight, longitudinally striated; between penultimate pinnae it bears four or five intercalary pinnae consisting of two lateral elements and a small, obovate terminal (Fig. 3a).

Penultimate pinnae subopposite and slightly overlapping in proximal parts, spaced and alternately attached in more distal parts; symmetrical, of ovate outline, with subparallel margins for most of their length, tapering gradually towards an imparipinnate apex. Dimensions: up to 100 $\mathrm{mm}$ length and $70 \mathrm{~mm}$ wide (basal part incomplete). Penultimate rachis inserted at c. $80-90^{\circ}$, straight, rounded, longitudinally striate, $0.6-0.9 \mathrm{~mm}$ wide. Small, orbicular, intercalary pinnules, one or two in number, occur between adjacent last order pinnae in direct attachment to this rachis (e.g., Figs 3b-3d).

Last order pinnae imparipinnate, alternate, closely spaced to well-separated, although never widely apart and, very occasionally, touching laterally. They are parallelsided for most of the length, bearing lateral pinnules of equal length up to near the terminal, and ending with a well-individualised, obovate pinnule, relatively large and, most noticeably, wider than the closely adjacent lateral pinnules in the shorter pinnae (Fig. 3a), and oval and more elongate in the longer ones (Figs 2a-2b, 3b-3c). The longest pinnae bear 10 pairs of lateral pinnules. Dimensions: 20$35 \mathrm{~mm}$ length and $8-13 \mathrm{~mm}$ wide; length/breadth ratio $=$ 2.5-2.7. Last order rachis inserted at c. $75-80^{\circ}$, straight, rounded in transverse section, longitudinally striated, 0.1$0.4 \mathrm{~mm}$ wide.

Lateral pinnules alternate or subopposite, contiguous or slightly distant, inserted at $45-90^{\circ}$. Pinnules ovate to subrectangular, with slightly convex margins and rounded apices. Pinnules inserted most commonly on a short, broad stalk which appears twisted in some specimens; high 

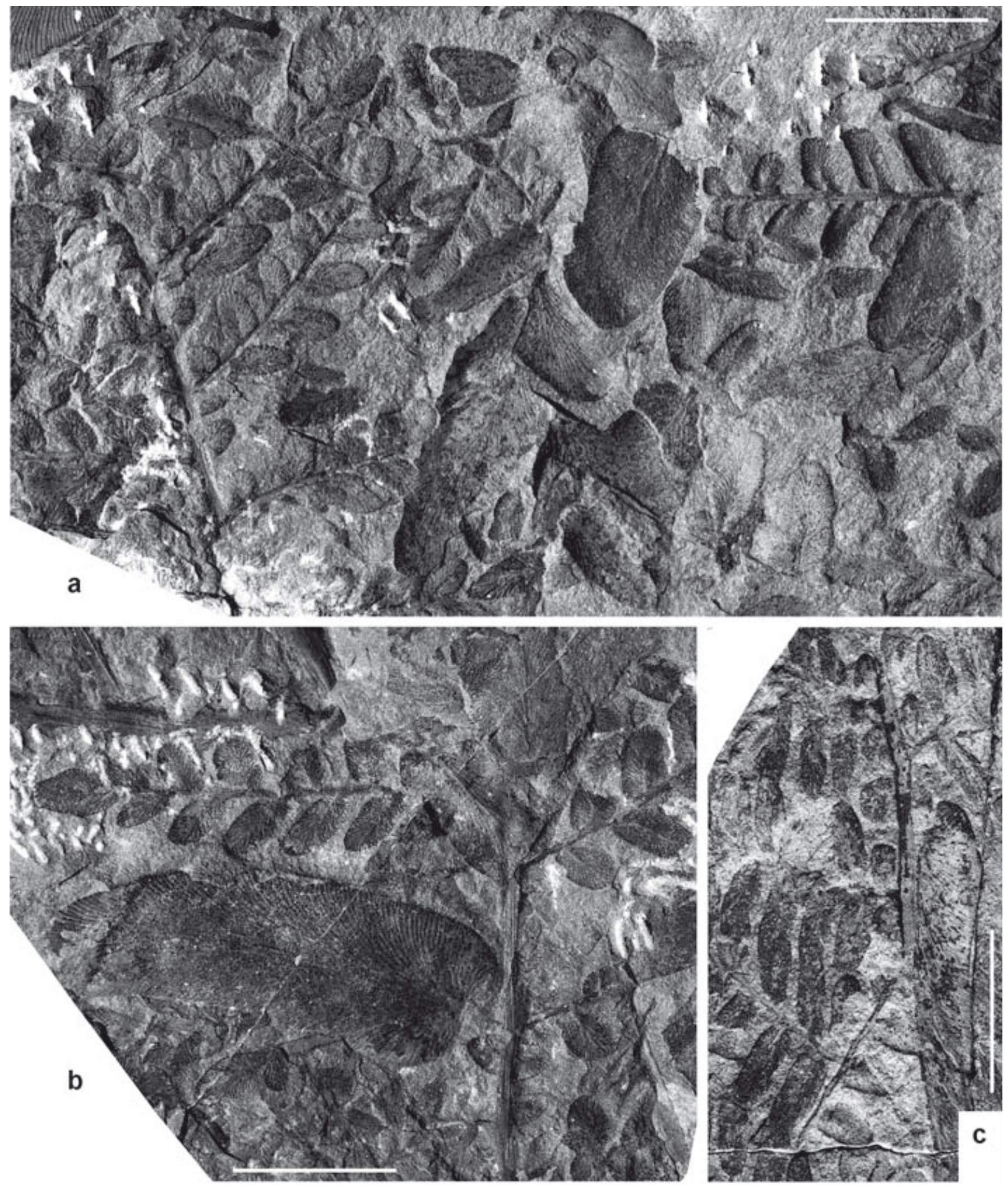

Figure 2. Wagneropteris minima gen. and sp. nov. a) PBE01993 (x 3). Penultimate order fragment previously figured as Neuropteris sp. nov. by Álvarez-Vázquez (1995, lám. 9, figs 3-3b); together with Neuropteris guadiatensis Wagner. Origin: Pozo (shaft) Aurora, cross-cut level 60, roof of the third rider seam, Seam 3 (locality 1646). b) PBE01994 (x 3). Penultimate order fragment; together with Paripteris gigantea (Sternberg) Gothan. Origin: same as for Fig. 2a (locality 1646). c) PBE02007 (x 3). Origin: borehole AB-9, 22 m. Scale bar 1 cm for all figures. Repository: Centro Paleobotánico, Real Jardín Botánico de Córdoba, Spain. 

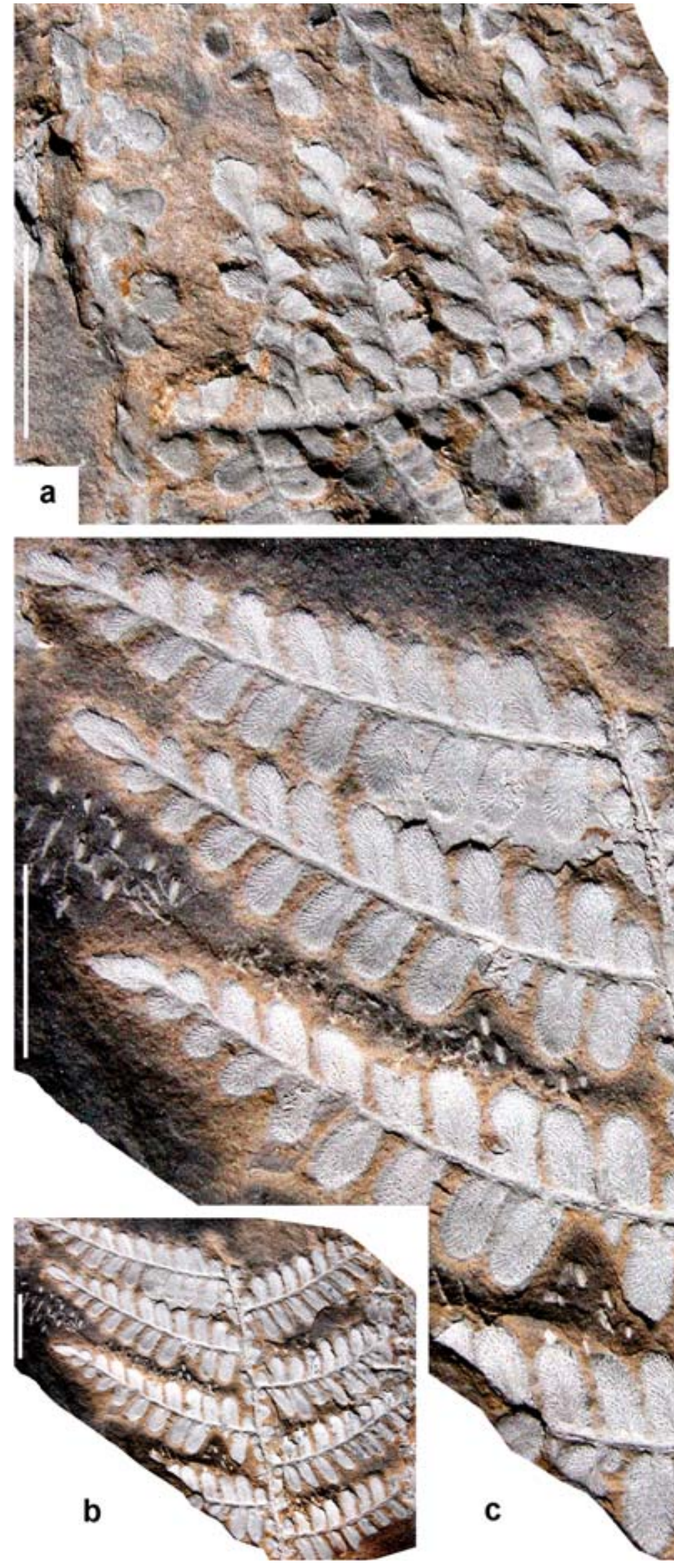

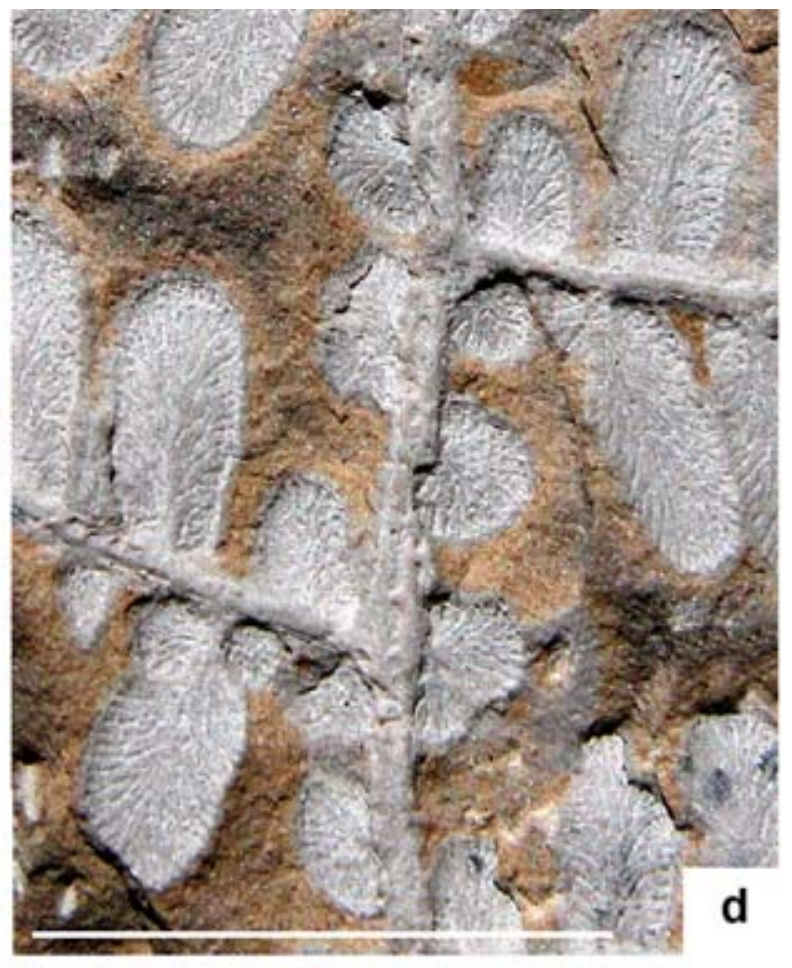

d 
in penultimate and ultimate order pinnae, the pinnules become partially attached to the rachis. Base cordate at both acroscopic and basiscopic sides in larger pinnules; some pinnules in basal parts of last order pinnae develop one or two rounded lobes (Figs 3d, 4d). Dimensions: 1-6 $\mathrm{mm}$ length and $1-2.5 \mathrm{~mm}$ width; length/breadth ratio = 1-2.4. First anadromous and catadromous pinnules of more reduced size, thus allowing space for intercalary pinnules on the penultimate rachis (e.g., Figs 3d, 4a, 4c). Anadromous pinnules are orbicular, very small, c. 1-1.25 $\mathrm{mm}$. Catadromous pinnules similar in shape to the standard laterals, but shorter, with half their length.

Lamina thick, vaulted, of fleshy appearance. Venation well-marked. Midrib straight, relatively wide (c. 0.15-0.20 $\mathrm{mm}$ ), prominent in the lower half of the larger pinnules; lateral veins emerge from the midrib at a narrow angle, curving gradually to reach the pinnule margins nearly perpendicularly, dichotomising up to two times (Figs 3d, 4d). In the smaller, more isodiametric pinnules there is not a developed midrib, and the veins arise from a common point. Vein density: c. $32-36$ veins per $\mathrm{cm}$ on the pinnule margin.

Remarks. Wagneropteris minima is a rare species, representing less than $1 \%$ of the palaeobotanical specimens collected from the basin (despite persistent collecting at the few localities where this species was found). It is mainly represented by small fragments of last order pinnae. In most cases, and always when preserved in the most coarse-grained material, Wagneropteris minima is the only species preserved in these samples. Where other species are associated, Neuropteris guadiatensis is found most often. Other species associated more occasionally, always with fragmentary remains, are Laveineopteris tenuifolia, Paripteris gigantea (Sternberg) Gothan, Mariopteris muricata (Schlotheim) Zeiller, Eusphenopteris nummularia (Gutbier) Novik and Sphenophyllum kidstonii Hemingway.

Comparisons. Wagneropteris minima is immediately recognisable by its very small pinnules and, in the larger specimens, by the presence of intercalary pinnules on the penultimate and antepenultimate rachises. Although several similar Namurian and early to middle Westphalian
Neuropteris species are also characterised by small pinnules, none of these possess intercalary pinnules.

Perhaps the most similar species is Neuropteris bohdanowiczii (Zalessky) Gothan, as recorded from Namurian A (Serpukhovian) strata of the Upper Silesian Basin (Zalessky, 1907, Taf. II, fig. 2, text-figs 9-10; copy in Crookall, 1959, text-fig. 41C; also figured by Gothan, 1913, Taf. 44, fig. 4, Taf. 53, fig. 1; Purkyňová, 1962, tab. XXIII, fig. 6; 1969, tab. I, fig. 1; 1970, Taf. XLIII, figs 1-2; 1977, pl. III, fig. 1; 1979, tab. II, fig. 5; Kotasowa, 1968, tab. XXX, figs 1, 2; tab. XXXI, fig. 3; and Migier, 1972, tab. XIX, fig. 2; 1973, tab. IV, fig. 1). This species, which Zalessky (1907, p. 33, 65) placed in Sphenopteris, shows ovoid pinnules of almost identical shape and dimensions to those of Wagneropteris minima. The tapering of last order pinnae and terminal shape are also very similar. However, apart from the lack of intercalary pinnules, the Silesian species also fails to show the reduction in size of the catadromous and anadromous basal pinnules required to accommodate the intercalary pinnules in Wagneropteris minima. Considering the size of the figured specimens, it appears that the absence of intercalary pinnules in Neuropteris bohdanowiczii is real and not the result of incomplete preservation. Additionally, it is noted that the vein density is higher in Neuropteris bohdanowiczii, viz. c. 40-45 veins per $\mathrm{cm}$ (as measured on the illustrations provided by Gothan, 1913 and Migier, 1972). The standard lateral pinnules of Neuropteris bohdanowiczii also tend to be more odontopteroid than those of Wagneropteris minima, but this character varies (in both species) depending on the position in the frond. Neuropteris bohdanowiczii has only been recorded reliably from the Upper Silesian Basin. We regard the specimen illustrated as Neuropteris bohdanowiczii from England (Crookall, 1959, pl. LV, figs 3-3a) as attributable to Crossotheca crepinii Zeiller.

Comparison can be made also with the Duckmantian/ Bolsovian species Neuropteris parvifolia Stockmans (1933, p. 28, pl. VIII, figs 1-5; see also Laveine, 1967, pl. LVI, figs 1-6a). However, this species has relatively broader and larger (4-20 mm length) lateral pinnules, a more flexuous midrib, and more strongly marked and widely spaced lateral veins $(25-28$ veins/cm as measured

Figure 3. Wagneropteris minima gen. and sp. nov. a) PBE01992 (x 3). Paratype. Antepenultimate pinna fragment showing the characteristic intercalary small pinnae on the antepenultimate rachis. Previously figured as Neuropteris sp. nov. by ÁlvarezVázquez (1995, lám. 10, fig. 1). Origin: ZE-1 (Exploratory trench 500 m SE Espiel), 113.60 m (locality 4830). b) PBE01989 (x 1). Holotype. Penultimate order fragment showing last order pinnae imparipinnate ending with a well-individualised, obovate pinnule, and showing the small, orbicular intercalary pinnules between adjacent last order pinnae in direct attachment to this rachis. Figured as Neuropteris sp. nov. by Álvarez-Vázquez (1995, lám. 10, figs 2-2a). Origin: same as for Fig. 3a (locality 4830). c) Enlargement (x 3) of holotype. d) Enlargement (x 6) of lower part of the holotype showing in detail the intercalary pinnules on penultimate rachis, and reduced size of basal anadromous and catadromous pinnules allowing space for intercalary pinnules. Note also the rounded lobes on basal pinnule. Scale bar $1 \mathrm{~cm}$ for all figures. Repository: Centro Paleobotánico, Real Jardín Botánico de Córdoba, Spain. 

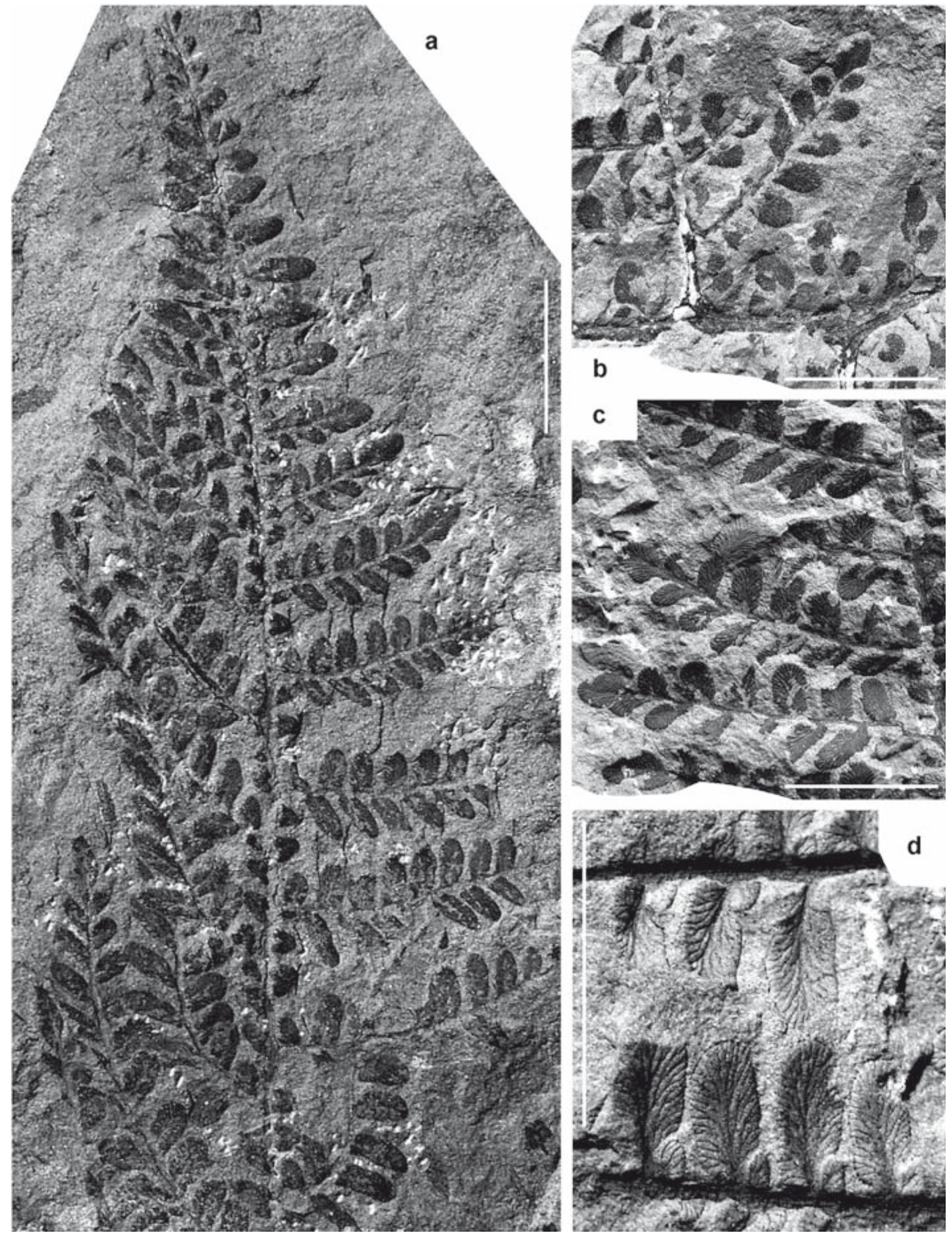
on the figures published by Stockmans, 1933 and Laveine, 1967). The apical pinnule is sub-rhomboidal, not ovoid as in Wagneropteris minima. Most significantly, Laveine (1967) and Cleal \& Shute (1995) interpreted Neuropteris parvifolia as belonging to the Neuropteris obliqual Neuropteris semireticulata complex, and so lacks the intercalary pinnules characteristic of Wagneropteris minima.

Wagneropteris minima also resembles another smallpinnuled form, Neuropteris willierei Laveine, 1967. The examples figured by Laveine (1967, pl. LXII, figs 1-4a, text-fig. 38) for this late Langsettian to early Duckmantian species from northern France are complemented by the specimens illustrated by Gothan (1953, Taf. 21, figs 1-3) as Imparipteris (Neuropteris) parvifolia Stockmans (see the synonymy presented by Laveine, 1967). The specimens illustrated by Laveine (1967) show fairly uniform, small, short, rather stubby pinnules, on average $2-3 \mathrm{~mm}$ long and $1.75-2.5 \mathrm{~mm}$ wide, with c. $35 \mathrm{veins} / \mathrm{cm}$ on the pinnule margin; these are inserted by part of the total width of the pinnule base. Those figured by Gothan (1953, Taf. 21, figs 1-1a, 3-3a) display relatively longer pinnules with a correspondingly more narrow attachment to the rachis. Anadromous pinnules in Gothan's specimens are very small (1-1.25 mm), orbicular and shorter than the others, whilst its catadromous pinnules have the same shape as the lateral pinnules. Laveine (1967, p. 226) points out that Neuropteris willierei shows an odontopteroid insertion of pinnules that is characteristic of the Neuropteris obliqua group. Although Wagneropteris minima tends to display a broader pinnule insertion in the near-terminal parts of pinnae, the average lateral pinnules in this species are inserted at a single point. Also, the pinnules of Neuropteris willierei characteristically show at least a few subsidiary veins apparently originating directly from the rachis; this is not the case in Wagneropteris minima. Additionally, the lateral veins are more widely spaced and flexuous in Laveine's species. Another difference is found in the shape of apical pinnules; these tend to be rhomboidal and longer in Neuropteris willierei and more ovoid (and on the whole, larger) in Wagneropteris minima. As in Neuropteris bohdanowiczii, the most important difference is the absence of intercalary pinnules on the penultimate rachises. Laveine (1967, p. 226) mentioned the possibility that Neuropteris willierei and Neuropteris bohdanowiczii might be synonymous, but the later, more complete illustration of Neuropteris bohdanowiczii by Purkyňová (1970) and Migier $(1972,1973)$ confirm that two different species are involved.

Stockmans (1933, pl. IX, figs 1-1b) figured as Neuropteris bockingiana a specimen from the Bolsovian of Belgium that has small, subtriangular pinnules similar to Wagneropteris but differs in not having a prominent midrib and the lateral veins being more oblique. The basionym of the species is Sphenopteris Böckingiana Weiss (1869, p. 49-50, Taf. VII, figs 1-1a; copy in Crookall, 1959, text-fig. 40) from the higher part of the Rotliegend of Schwarzenbach, Germany, a species that should probably be included in Pseudomariopteris. Crookall (1959) figured another specimen as Neuropteris bockingiana, from the Duckmantian of Yorkshire (op. cit., pl. LVII, fig. 3), but this is probably attributable to Laveineopteris loshii (Brongniart) Cleal, Shute \& Zodrow.

There are other records of Laveineopteris that superficially resemble Wagneropteris in pinnule form but because of their frond architecture (e.g., Laveine, 1996; Laveine et al., 2005) can have nothing to do with the latter fossil-genus. For instance, a specimen figured by Crookall (1959, pl. XXVIII, figs 2-2a) as Neuropteris heterophylla (and previously identified as Neuropteris microphylla by Kidston in MS) was included in Neuropteris loshii (= Laveineopteris loshii) by Laveine (1967, p. 145). This shows a pinna fragment of the penultimate order with very small pinnules similar to those figured in our Figure $4 c$. However, both pinna and pinnules are more densely spaced, touching laterally or even partially overlapping; they also show a shorter, less clearly marked midrib, and more oblique lateral veins.

Also similar is Laveineopteris rarinervis (Bunbury) Cleal, Shute \& Zodrow (and its synonym Imparipteris (Neuropteris) piesbergensis Gothan, 1953), which has small, subrectangular pinnules, with slightly convex margins, rounded to bluntly acuminate apices and cordate bases (see Laveine, 2005; Laveine et al., 2005). However, last order pinnae are more closely spaced or even partially overlapping, and the terminal is rhomboidal, larger and broader than the adjacent laterals. Pinnules in near-terminal parts of pinnae of the penultimate order and occurring higher in the frond show an appreciably larger size than the standard lateral pinnules. Venation density is lower, c. 22 veins $/ \mathrm{cm}$, with lateral veins one to three times forked and reaching the border at open angles (Laveine et al.,

Figure 4. Wagneropteris minima gen. and sp. nov. a) PBE05222 (x 2). Apical part of pinna showing transition between entire lateral pinnules and last order pinnae. Figured as Neuropteris minima (nomen nudum) in Wagner (2001, fig. 57). Origin: Corta (opencast) Candelaria, $40 \mathrm{~m}$ above Seam Candelaria (locality 9456). b) PBE05241 (x 3). Origin: Corta Candelaria, $2 \mathrm{~m}$ below Seam Candelaria (locality 9455). c) PBE05235 (x 3). Short, last order pinnae ending with wide, obovate pinnules. Origin: same as for Fig. 4b (locality 9455). d) PBE01989 (x 6). Specimen in the same piece as the holotype showing the loose venation and lateral veins two times forked. Origin: same as for Figs 3a-3b (locality 4830). Scale bar $1 \mathrm{~cm}$ for all figures. Repository: Centro Paleobotánico, Real Jardín Botánico de Córdoba, Spain. 


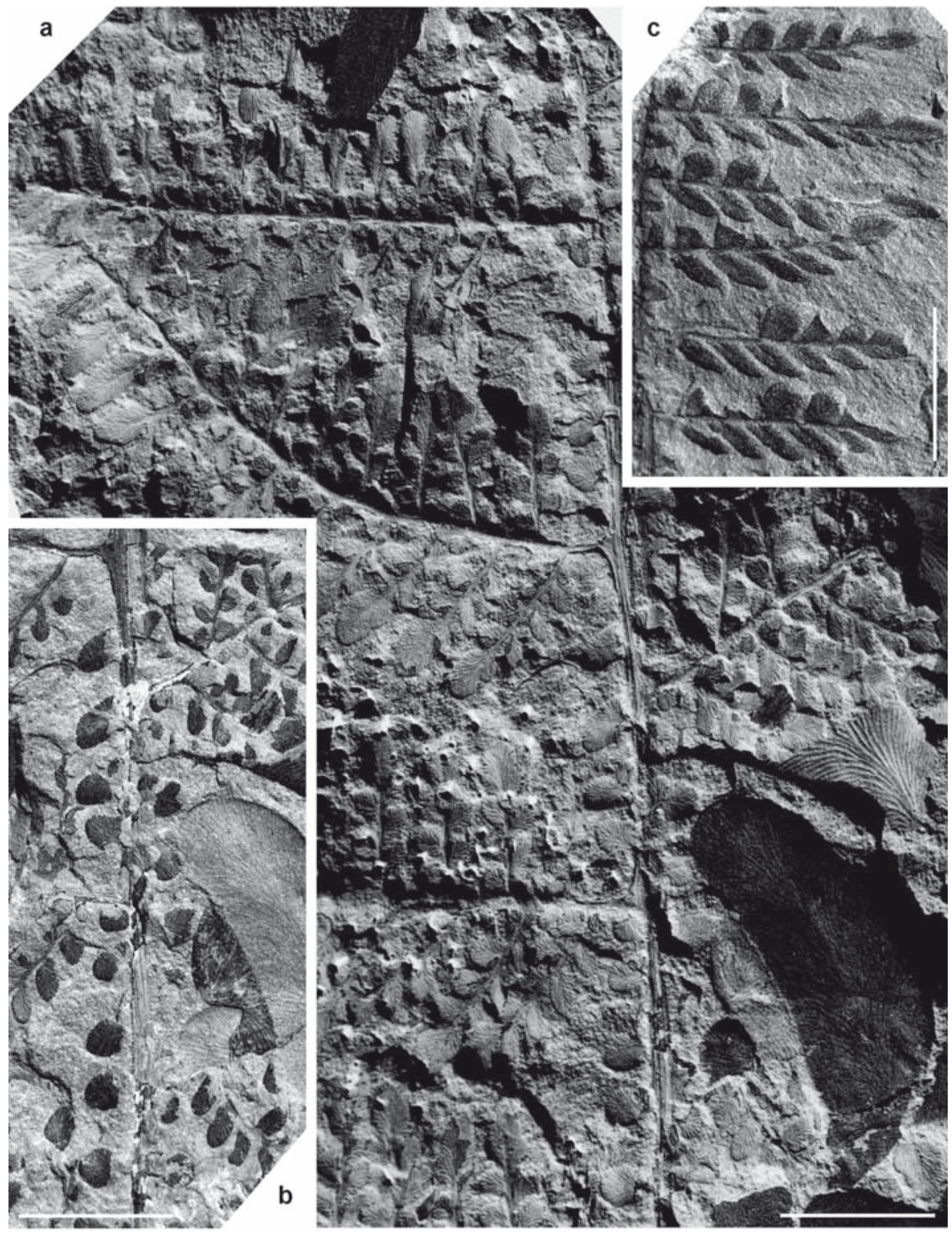


2005). In addition, there are no intercalary pinnules on the penultimate rachises.

Another similar species is Laveineopteris bohemica (Ettingshausen) Šimůnek \& Cleal, 2011 (and its synonym Neuropteris nikolausiana Gothan, 1913 - see Šimůnek \& Cleal, 2011, 2013). Like Wagneropteris, its pinnae have a relatively slender apical pinnule, and the lateral pinnules have a comparable subtriangular to linguaeform shape. However, the lateral pinnules tend to be more closely spaced and more consistently basally constricted, the veins a little less angular and the vein density rather lower (typically 26-30 per $\mathrm{cm}$ on the pinnule margin).

Neuralethopteris species can also have small pinnules similar to Wagneropteris, but again because of the differences in frond architecture (e.g., Laveine et al., 1992) the similarities are superficial. The lower Langsettian North American species Neuralethopteris pocahontas (White, 1900, p. 888, pl. CLXXXIX, figs 4-4a; pl. CXCI, figs 5-5a; Jongmans, 1937, pl. 13, figs 15-15a; pl. 14, figs 16-20a; pl. 16, fig. 27; pl. 17, fig. 30; Goubet et al., 2000, figs 5.35.6, 6, 7.3-7.7, 17.10; Blake et al., 2002, pl. XIV, figs 3, 4; pl. XV, fig. 9) is characterised by small pinnules, either oblong, with a cordate base, or rounded and broadly attached to the rachis. The lamina is also thick, convex, with rather widely spaced, well-marked lateral veins. The midrib is not clearly differentiated in the smaller pinnules, but well-marked, almost reaching the apex in the more elongate ones; secondary veins are twice forked, and meet the pinnule margin at a wide. Once again, the first anadromous and catadromous pinnules of last order pinnae are not reduced in size and no intercalary pinnules are present on the penultimate rachises of Neuralethopteris pocahontas.

There is some similarity with Neuralethopteris weilii Josten \& van Amerom (2003, p. 53-55, Taf. 100, figs 1-4; Taf. 101, fig. 6; Taf. 107, figs 1-2; Taf. 108; Taf. 110, figs 3-5; Abb. 72, 73, 78), a species from middle Namurian (B) strata of the Vorhaller Schichten, Westphalia, western Germany. Neuralethopteris weilii is distinguished at first sight from all other Neuralethopteris by its small pinnule size, 6-7 mm long and 1-2 $\mathrm{mm}$ wide according to the original diagnosis. The species is closely similar to Wagneropteris minima not only by its pinnule size, but also by its ovoid to subrectangular lateral pinnules with slightly convex margins and rounded apex (compare mainly Josten \& van Amerom's Tafn 107, 108 and Figs 4a, $5 \mathrm{a}, 6 \mathrm{c}$ and 8 in the present work), and by its well-marked, widely spaced lateral veins, forked up to three times, but the lack of intercalary pinnules on last order rachises separates both species.

Another small pinnuled species from the Namurian of Belgium, Neuropteris mathieui, was described by Stockmans \& Willière (1953, p. 227) on a single specimen from the Assise de Chokier previously determined as Neuropteris antecedens Stur by Renier (MS). Although Neuropteris mathieui was included in the synonymy of Neuropteris antecedens by Cleal \& Shute (1995), we regard it as a separate species. The type specimen of Neuropteris mathieui (Stockmans \& Willière, 1952, pl. XII, figs 3, 3a) shows small, ovoid pinnules, with slightly convex margins, rounded apex, and a slightly decurrent base. In the same paper, Stockmans \& Willière introduced another species, Neuropteris waltonii (op. cit., 1952-53, p. 227-228, pl. XII, figs 1-1a), based on a specimen included in Neuropteris smithsii (= Neuralethopteris smithsii) by Renier (MS). Stockmans \& Willière (op. cit.) noticed the similarities with both Neuropteris pocahontas (= Neuralethopteris pocahontas) and Neuropteris antecedens. Cleal \& Shute (1995, p. 31) maintained Neuropteris waltonii as a separate species including it in nomina dubia, as regards its generic position. According to Stockmans \& Willière's figuration, Neuropteris waltonii lateral pinnules are small (up to 6 $\mathrm{mm}$ ), ovoid, with a cordate or partly attached base and a rounded apex; the midrib is not clearly differentiated, and lateral veins fork one or two times. Terminals are wellindividualised, ovoid and relatively large and wide. We propose to recognise Neuropteris mathieui and Neuropteris waltonii as synonymous, the specific name waltonii (first figured) being the valid one. Again, the lack of intercalary pinnules on last order rachises clearly separates this Belgian species from Wagneropteris minima.

There are also some similarities with the type of Neuropteris microphylla Brongniart (1831, p. 245, pl. 74, figs 6-6a; copy, as Neuropteris heterophylla Brongniart, in Crookall, 1959, text-fig. 35). However, Lesquereux (1880, p. 107) compared it with his Neuropteris smithsii (Lesquereux, 1880, p. 106, pl. XIII, figs 1-3a), a species now included in Neuralethopteris (Goubet et al., 2000). Both have small, broadly oval to rounded lateral pinnules with a cordate base, and ovoid, well-individualised terminals (for instance, compare Brongniart's specimen with Goubet et al., 2000, figs 9.1-9.2); both moreover originated from North American localities. It is also notable that specimens from the Carboniferous of Taninges (Alps Maritimes, France), identified as Neuropteris microphylla by Heer (1876), were included in Neuralethopteris

Figure 5. Wagneropteris minima gen. and sp. nov. a) PBE05236 (x 3). Antepenultimate element showing intercalary small pinnae in antepenultimate rachis; together with isolate pinnules of Neuropteris guadiatensis Wagner. Origin: Corta Candelaria, $2 \mathrm{~m}$ below Seam Candelaria (locality 9455). b) PBE05224 (x 3). Counterpart (compression) of lower part of specimen in Fig. 5a. Origin: same as for Fig. 5a (locality 9455). c) PBE01965 (x 3). Origin: borehole SEP-4, 223.30 m (locality 5462). Scale bar $1 \mathrm{~cm}$ for all figures. Repository: Centro Paleobotánico, Real Jardín Botánico de Córdoba, Spain. 

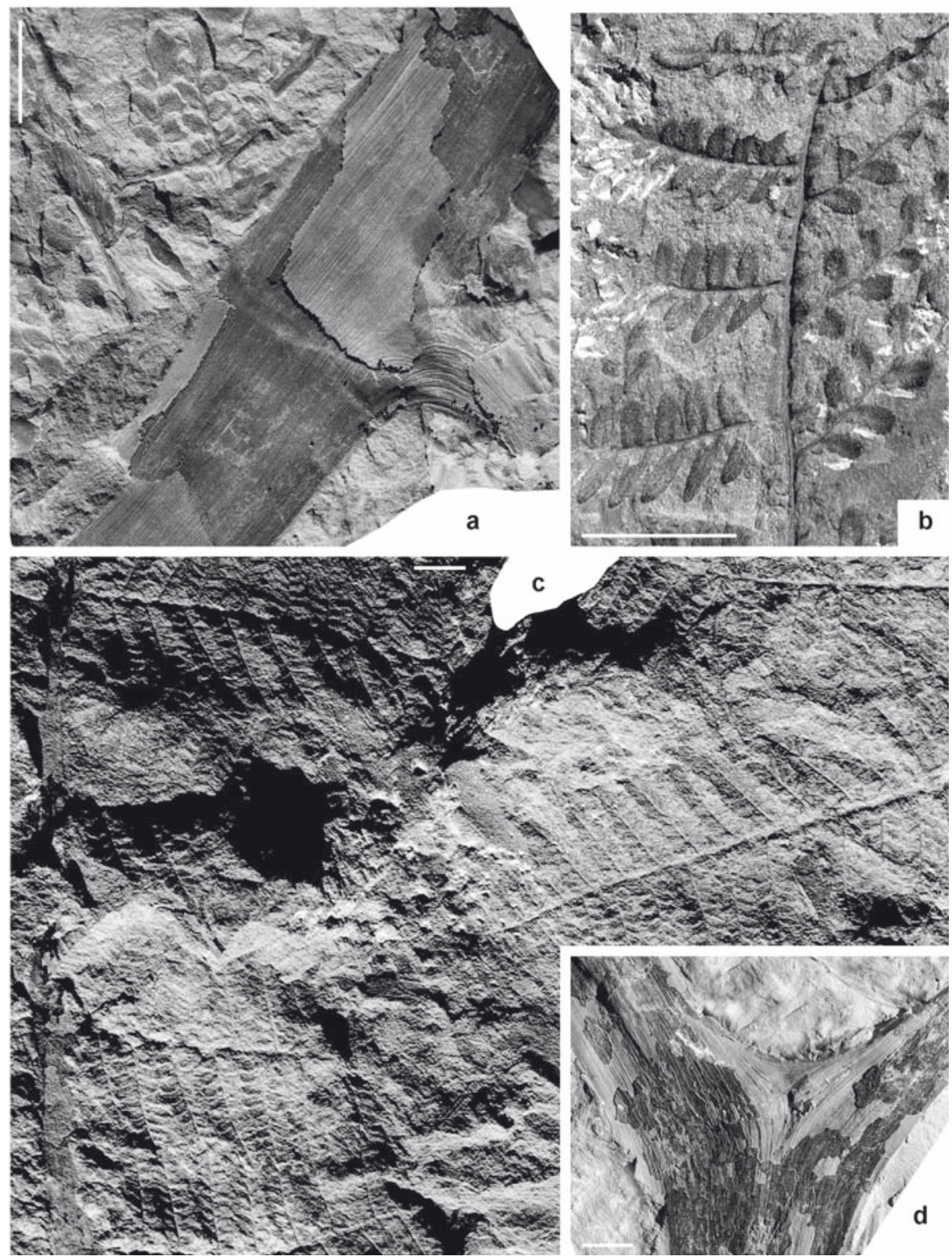

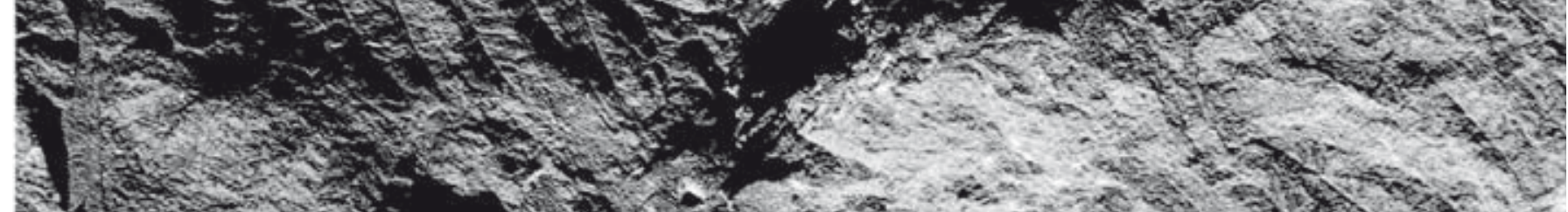

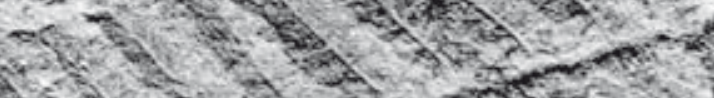

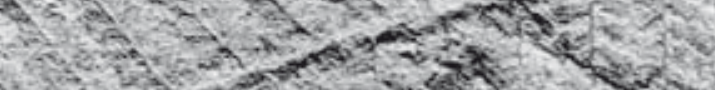

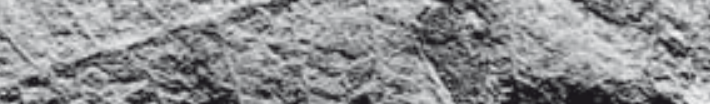

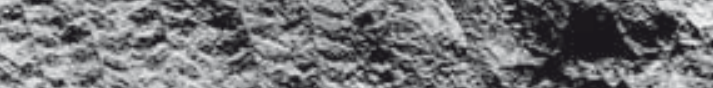

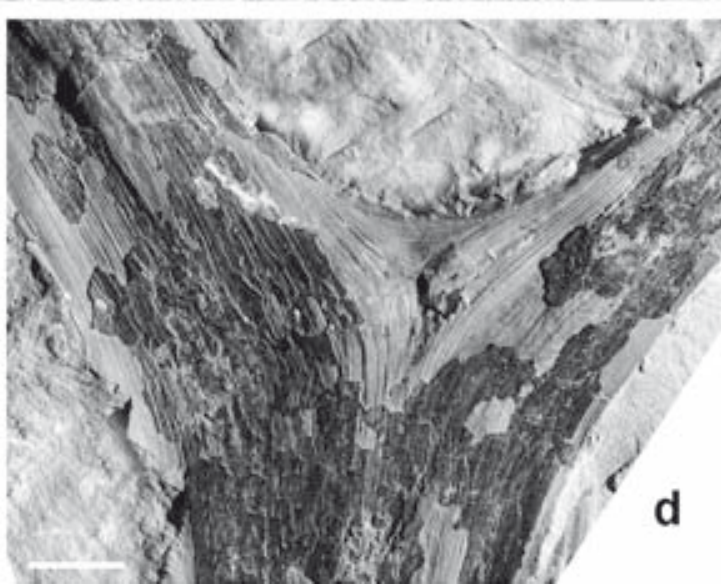


schlehanii by Brousmiche Delcambre et al. (1998). If the attribution of the type Neuropteris microphylla to Neuralethopteris can be confirmed, there can be no question of identifying this with Wagneropteris minima, which has a completely different frond architecture.

Schultka (1995, Taf. 28, figs 3, 4, 7) figured as Neuropteris cf. condrusiana two specimens from the Namurian B of Westphalia, western Germany, with very small (c. $2 \mathrm{~mm}$ ) pinnules but showing a large terminal (c. $7 \mathrm{~mm}$ ). Another specimen assigned in the same paper to Neuropteris mathieui (Schultka, 1995, Taf. 29, figs 5-6) shows small pinnules with similar shape to those assigned to Wagneropteris minima (compare particularly with our Figs 2a-2b, 3b-3c, 4a), but again the lack of intercalary pinnules is definitive. Also the small-pinnuled specimens figured as Neuropteris condrusiana by Leggewie \& Schonefeld (1960, Taf. 28, figs 1-15) show a certain similarity with Wagneropteris minima, but the lack of intercalary pinnules on the antepenultimate order rachis of the only fragment of the penultimate order figured is clear.

Neuropteris gliwicensis Kotasowa (1975, p. 205-206, tab. XI, figs 1-1b; tab. XII, figs 1-1a) is another smallpinnuled species described from Namurian A strata of the Petřkovice Beds, Polish part of the Upper Silesian Coal Basin. The orbicular to oval-shaped pinnules, attached to the rachis at a point, and the fan-shaped venation, with all veins converging in the same point, together with the lack of intercalary pinnules easily separate this species from Wagneropteris minima.

Distribution. Wagneropteris minima appears to be restricted to lower Bolsovian strata of the PeñarroyaBelmez-Espiel Coalfield.

\section{REMARKS ON SYSTEMATIC POSITION}

The fossil-generic and -family classification of the medullosalean fronds is based mainly on frond-architecture, supplemented by epidermal anatomy and to a certain extent pinnule morphology and venation (we are using here fossilgenera and -families in the sense of Cleal \& Thomas, 2010). Laveine (1997) recognised three main architectural styles for these fronds:
1. Bifurcate-pinnate fronds. These are characterised by a main dichotomy of the primary rachis near the base of the frond, producing two pinnate branches (primary pinna branches sensu Cleal \& Shute, 1991, which, where known, are usually tripinnate). The ultimate pinnae are terminated by a single apical pinnule (imparipinnate condition) and there are no intercalated pinnae or pinnules on the subsidiary rachises. The best-known examples of this frond-type include Alethopteris Sternberg, Neuralethopteris Cremer and Lonchopteris Brongniart (Laveine et al., 1992) and were classified by Cleal \& Shute (2003) as the fossilfamily Alethopteridaceae.

2. Pseudo-pinnate fronds. Such fronds were interpreted by Laveine (1997) as being produced by a repeatedly bifurcating system, but because of strong over-topping results in a superficially pinnate architecture (Laveine et al., 1993). Characteristic features of these fronds include the absence of a basal dichotomy, ultimate pinnae being terminated by a pair of pinnules (paripinnate condition), pinnules being always unlobed and being attached directly to orders of rachis. These fronds are best known in Paripteris Gothan and Linopteris Presl, and were classified by Cleal \& Shute (2003) as the fossil-family Parispermaceae.

3. Bifurcate-semi-pinnate. These also have a main dichotomy of the main rachis near the base of the frond. However, the resulting branches (primary rachis branches) here undergo a series of bifurcations, and because they are strongly overtopped give a superficially pinnate appearance. Critically, this results in foliar elements borne on the primary rachis branches being intercalated between secondary pinnae; these are intercalated pinnae if (as usual) the primary rachis branches are tri/ quadripinnate, intercalated pinnules in those fronds where the primary rachis branches are bi/tripinnate. In some cases there are also intercalated pinnules on the penultimate rachises between the ultimate pinnae (e.g., in Callipteridium - see Wagner, 1965) but the structural position of these appears to be

Figure 6. Wagneropteris minima gen. and sp. nov. a) PBE07000 (x 2). Large (primary), longitudinally striated rachis associated with antepenultimate order pinnae of Wagneropteris minima; note at right hand the departure of a lateral rachis. Origin: Corta La Ballesta, 2 m below Seam 8 (locality 10487). b) PBE01979 (x 3). Penultimate order fragment. Origin: borehole SEP-10, $176.60 \mathrm{~m}$ (locality 6743). c) PBE05221 (x 1). Large specimen preserved in fine-grained sandstone showing part of two different antepenultimate pinnae, the one at right attached to a wide rachis. Origin: Corta Candelaria, $40 \mathrm{~m}$ above Seam Candelaria (locality 9456). d) PBE07001 (x 1). Specimen showing the main bifurcation of a frond; associated with penultimate and ultimate order fragments of Wagneropteris minima. Origin: same as for Fig. 6a (locality 10487). Scale bar $1 \mathrm{~cm}$ for all figures. Repository: Centro Paleobotánico, Real Jardín Botánico de Córdoba, Spain. 


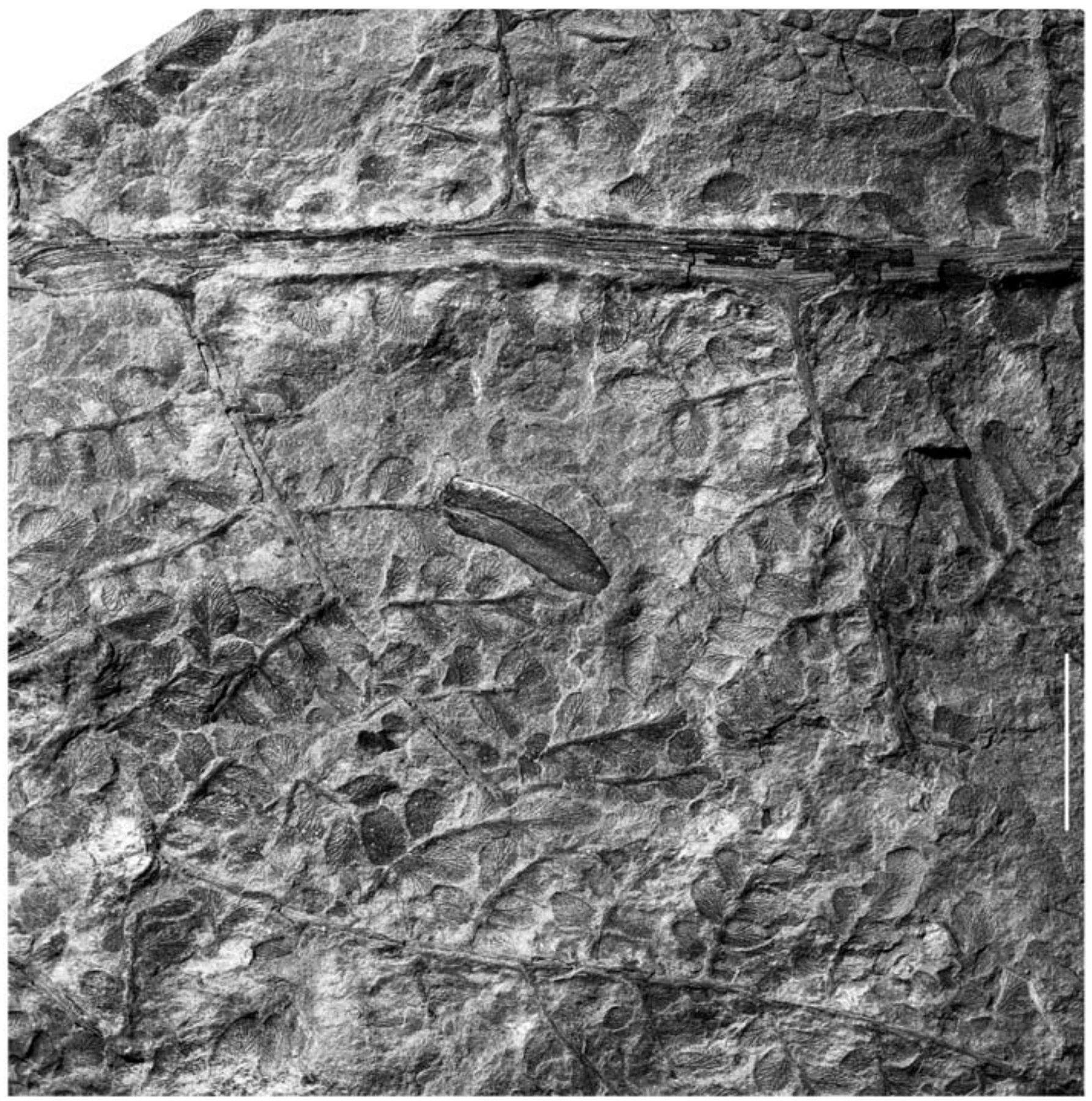

Figure 7. Wagneropteris minima gen. and sp. nov. PBE07000 (x 3). Antepenultimate fragment associated with the large rachis figured in Fig. 6a, showing characteristic medium-sized pinnules. Together with a small, isolate pinnule of Laveineopteris tenuifolia (Schlotheim ex Sternberg) Cleal, Shute \& Zodrow. Origin: Corta La Ballesta, 2 m below Seam 8 (locality 10487). Scale bar $1 \mathrm{~cm}$. Repository: Centro Paleobotánico, Real Jardín Botánico de Córdoba, Spain.

unrelated to the intercalated pinnae on the primary rachis branches. All pinnae are terminated by a single apical pinnule (imparipinnate condition). These fronds were classified by Cleal \& Shute (2003) as the fossil-family Cyclopteridaceae (e.g., Laveineopteris Cleal, Shute \& Zodrow, Callipteridium Weiss) if they had cyclopterid leaves attached to the basal part of the frond, or Neurodontopteridaceae (e.g.,
Neuropteris Brongniart, Macroneuropteris Cleal, Shute \& Zodrow, Odontopteris Brongniart) if they lacked cyclopterids.

The presence of a basal dichotomy of the primary rachis, the imparipinnate condition of the pinnae and the presence of intercalated pinnae on the primary rachis branches (antepenultimate rachises) clearly points to the 


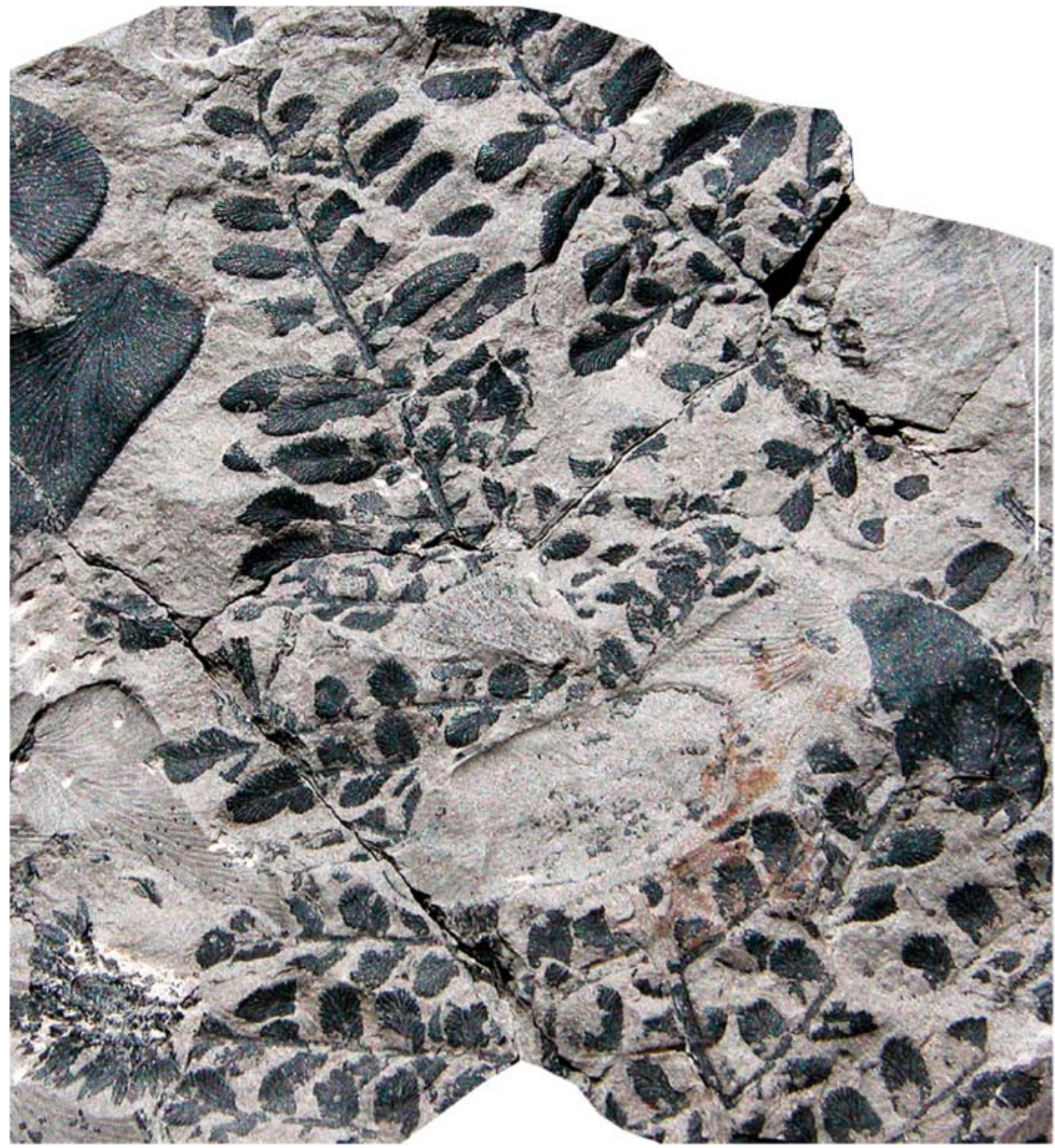

Figure 8. Wagneropteris minima gen. and sp. nov. PBE05234 (x 5). Apical part of penultimate pinna; together with Neuropteris guadiatensis Wagner and Potoniea sp. Origin: Corta Candelaria, $2 \mathrm{~m}$ below Seam Candelaria (locality 9455). Scale bar $1 \mathrm{~cm}$. Repository: Centro Paleobotánico, Real Jardín Botánico de Córdoba, Spain.

Wagneropteris frond having a bifurcate semi-pinnate architecture. The presence of intercalated pinnules on the secondary (penultimate) rachises clearly places this genus near to the type of Callipteridium ("Eucallipteridium" sensu Wagner, 1965), which also shows this feature.
However, Callipteridium tends to have much stouter, more lingulate pinnules and intercalated pinnae rather than pinnules on the primary rachis branches. Laveine et al. (1977) suggested that it would be possible to achieve pinnules on the primary rachis branches by condensing 


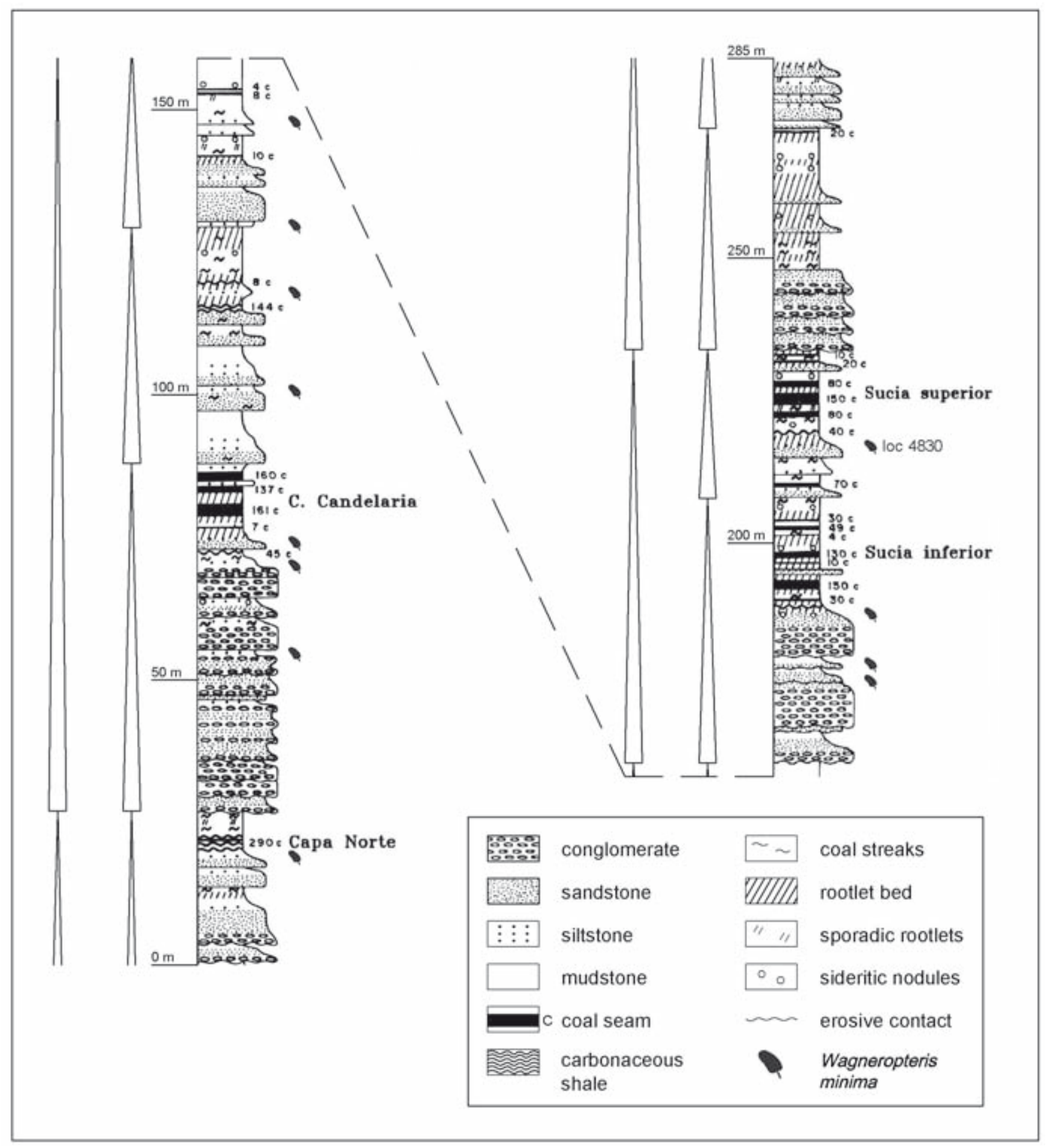

Figure 9. Stratigraphic column of the succession in the area of Espiel showing the position of type locality and other localities with Wagneropteris minima in this area.

the development of the frond (growth retardation sensu Laveine, 1967). However, in the case of Wagneropteris this would imply that growth retardation would be occurring in one part of the frond (the primary rachis branches) and not another (the secondary pinnae) - not impossible, but not previously reported in medullosalean fronds.
Other fossil-taxa allied to Callipteridium (Callipteridium) are Callipteridium (Praecallipteridium) Wagner, Margaritopteris Gothan and Palaeoweichselia Potonié \& Gothan (see Laveine et al., 1977 for a discussion of this relationship). However, these all differ from Wagneropteris in not having discrete intercalated pinnules on the secondary (penultimate) rachises. 
If this relationship with Callipteridium can be corroborated, it would imply that Wagneropteris belongs to the fossil family Cyclopteridaceae sensu Cleal \& Shute (2003), a position we have provisionally accepted here. It would also imply that Wagneropteris would have cyclopteroid foliar structures attached to the base of the frond (see Shute \& Cleal, 2002 for a discussion on the nature of these structures, although an alternative counterview is robustly given by Laveine, 2005). There are indeed cyclopterids reported from the Peñarroya-BelmezEspiel Coalfield (Wagner, 1983b; Cleal \& Shute, 1995) but not attached to any fronds. It should also be noted that in Late Pennsylvanian (Stephanian) Callipteridium species the cyclopterids tend to be small structures that are rarely found isolated (Wendel, 1980) and so rather different from the Peñarroya-Belmez-Espiel cyclopterids.

If this systematic position for Wagneropteris proves correct, it will be one of the earliest known Callipteridiumlike Cyclopteridaceae fronds. The only fossil-species in this complex of comparable age is Margaritopteris conwayi (Lindley \& Hutton) Crookall (Crookall, 1976; Laveine et al., 1977). However, this would complicate the elegant phylogenetic model based on these fronds by Laveine et al. (1977) whereby there is a progressive reduction in size and pinnate division (growth retardation) through middle and late Pennsylvanian times.

\section{HABITAT}

As mentioned before, Wagneropteris minima is a rare element of the Peñarroya flora. It is also noted that it either occurs alone or in association with only a few other species. It is further noted that it occurs in relatively coarse sediments, i.e., fine sandstones and siltstones which form part of fining upward sequences of fluviatile facies (as shown in the stratigraphic section of Fig. 9, containing the type locality). Where other species are associated, their remains are always very fragmentary, as corresponds to a fluviatile environment. On the other hand, there is no evidence of orientation as would correspond to deposition in a river bed with diminished stream flow. Perhaps, Wagneropteris minima lived on marginally higher ground adjoining streams in a braided river setting. There are not necessary levees as would correspond to more major rivers.

\section{GENERAL CONCLUSIONS}

Wagneropteris minima is a rare species, to date known only from (upper Duckmantian?) lower Bolsovian strata of the Peñarroya Basin. It represents less than $1 \%$ of the total macroflora of the basin, despite the record of 298 specimens from 40 localities having been found. It is interpreted as a medullosalean frond, probably of the fossil-family Cyclopteridaceae, and with affinities with the Callipteridium-complex of fronds. However, it shows a unique set of characters that has caused us to assign it to its own, new fossil-genus. If our interpretation is correct, this is a very early representative of this group of medullosaleans, which became important components of some mid-Stephanian (Kasimovian as recognised with respect to the global stratigraphic framework) floras in the palaeoequatorial belt. It may also require us to re-evaluate the accepted phylogenetic model for these medullosaleans, which has tended to suggest a progressive reduction in size and division of the fronds. However, further data are clearly needed, in particular the epidermal structure and the relationship with possible cyclopterids.

\section{ACKNOWLEDGEMENTS}

The paper benefited from constructive comments and suggestions by John A. Knight and Jason Hilton. C.A.-V. is grateful to Juan I. Peláez and mining engineers at ENCASUR coal company for providing access to collecting sites and stratigraphic data. Thanks are also given to Juan I. Peláez and Eva Peláez Álvarez for their unfailing support and help in fieldwork.

\section{REFERENCES}

Álvarez-Vázquez, C. 1995. Macroflora del Westfaliense inferior de la cuenca de Peñarroya-Belmez-Espiel (Córdoba). PhD Thesis, Department of Geology, University of Oviedo (unpublished).

Álvarez-Vázquez, C. 1999. Nuevos datos aportados por la macroflora a la datación y conocimiento de la cuenca carbonífera de Peñarroya-Belmez-Espiel (Córdoba, SO España). Trabajos de Geología, 21, 37-46.

Apalategui Isasa, O., Garrote Ruíz, A., Roldán García, F.J. \& Sánchez Carretero, R. 1985. Mapa Geológico de España, E. 1:50.000. Hoja $n^{\circ}$ 879, Peñarroya-Pueblonuevo. Instituto Geológico y Minero de España.

Blake, B.M., Cross, A.T., Eble, C.F., Gillespie, W.H. \& Pfefferkorn, H.W. 2002. Selected plant megafossils from the Carboniferous of the Appalachian Region, eastern United States: geographic and stratigraphic distribution. In: Carboniferous and Permian of the World (eds. Hills, L.V., Henderson, C.M. \& Bamber, E.W.). Proceedings XIV International Congress Carboniferous and Permian Stratigraphy, Calgary, Alberta 1999, Canadian Society of Petroleum Geologists, 19, 259-335. 
Brongniart, A. 1828-1838. Histoire des végétaux fossiles, ou Recherches botaniques et géologiques sur les végétaux renfermés dans les diverses couches du globe. Texte: I (1828-1837): 1 (1828): i-xii, 1-80; 2 (1828): 81-136; 3 (1829): 137-168; 4 (1830): 169-208; 5 (1831): 209-248; 6 (1831): 249-264; 7 (1833): 265-288; 8 (1834): 289-312; 9 (1834): 313-316; 10 (1836): 337-368; 11 (1837): 369-416; 12 (1837): 417-488. II (1837-1838) - 13 (1837): 1-24; 14 (1838): 25-56; 15 (1838): 57-72; Atlas: I - pls 1-166; II - pls 1-30. Facsimile Edition W. Junk, Berlin (1915).

Brongniart, A. 1843. Énumeration des genres de plantes cultivés au Muséum d'Histoire Naturelle de Paris. Fortin, Masson \& Cie Libraires, Paris, 1-136.

Brousmiche Delcambre, C., Coquel, R., Mercier, D. \& Sartori, M. 1998. Révision du Carbonifère de Taninges (Préalpes du Chablais) - Paléobotanique - Palynologie. Revue de Paléobiologie, Genève, 17 (2), 549-563.

Cleal, C.J. 2008. Palaeofloristics of Middle Pennsylvanian medullosaleans in Variscan Euramerica. Palaeogeography, Palaeoclimatology, Palaeoecology, 268, 164-180; doi:10.1016/j.palaeo.2008.03.045.

Cleal, C.J. \& Shute, C.H. 1991. The Carboniferous pteridosperm frond Neuropteris heterophylla (Brongniart) Sternberg. Bulletin of the British Museum (Natural History), Geology Series, 46 (2), 153-174.

Cleal, C.J. \& Shute, C.H. 1995. A synopsis of neuropteroid foliage from the Carboniferous and Lower Permian of Europe. Bulletin of the Natural History Museum, Geology Series, 51 (1), 1-52.

Cleal, C.J. \& Shute, C.H. 2003. Systematics of the Late Carboniferous medullosalean pteridosperm Laveineopteris and its associated Cyclopteris leaves. Palaeontology, 46 (2), 353-411; doi:10.1111/1475-4983.00303.

Cleal, C.J. \& Shute, C.H. 2012. The systematic and palaeoecological value of foliage anatomy in Late Palaeozoic medullosalean seed-plants. Journal of Systematic Palaeontology, 10 (4), 765-800; doi:10.1080/ 14772019.2011.634442.

Cleal, C.J. \& Thomas, B.A. 2010. Botanical nomenclature and plant fossils. Taxon, 59 (1), 261-268; doi:10.2307/27757068.

Cleal, C.J., Laveine, J.-P. \& Shute, C.H. 1996. Architecture of the Upper Carboniferous pteridosperm frond Macroneuropteris macrophylla. Palaeontology, 39 (3), 561-582.

Corsin, P. 1960. Classification des Ptéridophytes et des Ptéridospermophytes du Carbonifère. Bulletin de la Société géologique de France, Série 7, 2, 566-572.

Crookall, R. 1959. Fossil plants of the Carboniferous rocks of Great Britain. (Second Section). Memoirs of the Geological Survey of Great Britain, Palaeontology, IV (2), 85-216.

Crookall, R. 1976. Fossil plants of the Carboniferous rocks of Great Britain. (Second Section). Memoirs of the Geological Survey of Great Britain, Palaeontology, IV (7), 841-1004.

DiMichele, W.A., Phillips, T.L. \& Pfefferkorn, H.W. 2006. Paleoecology of Late Paleozoic pteridosperms from tropical Euramerica. Journal of the Torrey Botanical Society, 133 (1), 83-118.
Dix, E. 1934. The Sequence of Floras in the Upper Carboniferous, with Special Reference to South Wales. Transactions of the Royal Society of Edinburgh, 57, 789-838.

ENADIMSA 1977. Investigación geológico minera de la cuenca carbonifera del Guadiato. Empresa Nacional Adaro de Investigaciones Mineras, S.A. (unpublished report).

Gothan, W. 1913. Die Oberschlesische Steinkohlenflora. I. Farne und farnähnliche Gewächse (Cycadofilices bezw. Pteridospermen). Abhandlungen der Königlich Preussischen Geologischen Landesanstalt, Neue Folge, $75,1-278$.

Gothan, W. 1953. Die Steinkohlenflora der westlichen paralischen Steinkohlenreviere Deutschlands. Beihefte zum Geologischen Jahrbuch, 10, 1-83.

Goubet, P., Pfefferkorn, H.W. \& Gillespie, W.H. 2000. Neuralethopterids (Trigonocarpalean Pteridosperms) from the Early Pennsylvanian of eastern North America. PaleoBios, 20 (3), 11-37.

Heer, O. 1876. Die vorweltliche Flora der Schweiz. 1. Die Steinkohlenflora. J. Wurster \& Co, Zurich, 1-60.

Jongmans, W.J. 1937. Comparison of the floral sucession in the Carboniferous of West Virginia with Europe. Compte Rendu $2^{e}$ Congrès pour l'avancement des études de Stratigraphie Carbonifère, Heerlen 1935, I, 393-415.

Josten, K.-H. \& Amerom, H.W.J. van 2003. Die Flora des Namur B aus Hagen-Vorhalle. Geologie und Paläontologie in Westfalen, 61, 1-303.

Kotasowa, A. 1968. The flora of the productive Carboniferous in the north-eastern part of the Upper Silesian Coal Basin (Dabrowa District). Instytut Geologiczny, Prace, LII, 1-88 (in Polish with English abstract).

Kotasowa, A. 1975. Flora of the Petrrkovice Beds in Coal Mine Gliwice. Instytut Geologiczny, Biuletyn 282, XIII, 169-207 (in Polish with English summary).

Laveine, J.-P. 1967. Contribution à l'étude de la flore du Terrain Houiller. Les Neuroptéridées du Nord de la France. Études géologiques pour l'Atlas de Topographie souterraine, Service Géologique des H.B.N.P.C. I. Flore fossile, 5. Texte: 1-344, pls A-H, J-K, M-P; Atlas: pls I-LXXXIV.

Laveine, J.-P. 1996. Confirmation of the bifurcate semipinnate model of frond architecture for a historical specimen of Laveineopteris rarinervis (Bunbury 1847), Upper Carboniferous pteridosperm. Comptes Rendus de l'Académie des Sciences, Paris, série IIa, 322, 483-492.

Laveine, J.-P. 1997. Synthetic analysis of the Neuropterids. Their interest for the decipherment of Carboniferous palaeogeography. Review of Palaeobotany and Palynology, 95, 155-189; doi:10.1016/S0034-6667(96)00033-4.

Laveine, J.-P. 2005. The Cyclopteris of Laveineopteris (Late Carboniferous pteridosperm). Fancies and facts: methodological and taxonomical implications. Revue de Paléobiologie, Genève, 24 (2), 403-487.

Laveine, J.-P., Coquel, R. \& Loboziak, S. 1977. Phylogénie générale des Calliptéridiacées (Ptéridospermopsida). Geobios, 10, 757-847. 
Laveine, J.-P., Kahlert, E. \& Schultka, S. 2005. Frond architecture of two remarkable specimens of the pteridosperm Laveineopteris rarinervis from the Late Carboniferous (early Westphalian D) of Piesberg near Osnabrück (Germany): morphological implications. Revue de Paléobiologie, Genève, 24 (2), 489-504.

Laveine, J.-P., Lemoigne, Y., \& Zhang, S. 1993. General characteristics and paleobiogeography of the Parispermaceae (genera Paripteris Gothan and Linopteris Presl), pteridosperms from the Carboniferous. Palaeontographica, Abt. B, 230, 81-139.

Laveine, J.-P., Belhis, A., Lemoigne, Y. \& Zhang, S. 1992. Frond architecture in the genera Neuralethopteris Cremer, Alethopteris Sternberg and Lonchopteris Brongniart (Carboniferous pteridosperms). Revue de Paléobiologie, Volume spécial, 6, 149-166.

Leggewie, W. \& Schonefeld, W. 1960. Die Flora der Homoceras-Zone in den Untersten Grenzschichten der Herzkamper Mulde. Palaeontographica, Abt. B, 106 (46), 141-155.

Lesquereux, L. 1879-1884. Description of the Coal Flora of the Carboniferous Formations in Pennsylvania and throughout the United States. Second Geological Survey Pennsylvania. Report of Progress. Text - I (1880): 1-354; II (1880): 355-694; pls LXXXVI, LXXXVII; III (1884): 695-977; pls LXXXVIII-CXI. Atlas (1879): pls A, B; pls I-LXXXV.

Migier, T. 1972. A floristic description of the productive Carboniferous of the Upper Silesian Coal Basin. Instytut Geologiczny, Prace, 61, 135-182 (in Polish with English abstract).

Migier, T. 1973. Floristic description of the Poreba Beds (Namurian A) in the vicinity of Katowice and Chorzów. Kwartalnik Geologiczny, 17 (2), 247-251 (in Polish).

Ortuño, M.G. 1970. Middle Westphalian strata in SouthWest Spain. Compte Rendu 6e Congrès International de Stratigraphie et de Géologie du Carbonifère, Sheffield 1967, III, 1275-1292.

Purkyňová, E. 1962. Flóra produktivního karbonu ostravsko-karvinského revíru. Pracovní metody geologické služby, 3, 1-116 (in Czech).

Purkyňová, E. 1969. Karbonská flóra ze strukturního vrtu NP 522 v Tiché u Frenštátu pod Radhoštěm (hornoslezská pánev). Acta Musei Silesiae, Series A, 18, 129-140 (in Czech with German abstract).

Purkyňová, E. 1970. Die Unternamurflora des Beckens von Horní Slezsko (ČSSR). Paläontologische Abhandlungen, Abteilung B, Paläobotanik, III (2), 129-268.

Purkyňová, E. 1977. Namurian Flora of the Moravian Part of the Upper Silesian Coal Basin. In: Symposium on Carboniferous Stratigraphy (eds. Holub, V.M. \& Wagner, R.H.). Ústřední ústav geologický, Praha, 289-303.

Purkyňová, E. 1979. Fytopaleontologie karbonu ve strukturním vrtu Čeladná SV-6 (hornoslezská pánev). Casopis Slezského Muzea, Opava, Series A, 28, 187-190 (in Czech with German abstract).

Schultka, S. 1995. Die Flora des Namur B in der ehemaligen Ziegeleitongrube Voßacker bei Fröndenberg. Eine
Übersicht. Geologie und Paläontologie in Westfalen, 35, 1-97.

Shute, C.H. \& Cleal, C.J. 2002. Ecology and growth habit of Laveineopteris: a gymnosperm from the Late Carboniferous tropical rain forests. Palaeontology, 45 (5), 943-972; doi:10.1111/1475-4983.00270.

Šimůnek, Z. \& Cleal, C.J. 2011. Imparipinnate neuropteroid foliage (Medullosales) from the middle Westphalian of the West and Central Bohemia Coal Basin, Czech Republic. Review of Palaeobotany and Palynology, 166, 163-201; doi:10.1016/j.revpalbo.2011.05.005.

Šimůnek, Z. \& Cleal, C.J. 2013. The epidermis of cyclopteroid Laveineopteris bohemica (Medullosales) from the Middle Pennsylvanian Radnice Member, Czech Republic. Bulletin of Geosciences, 88, 63-67.

Stidd, B.M. 1981. The current status of medullosan seed ferns. Review of Palaeobotany and Palynology, 32, 63101; doi:10.1016/0034-6667(81)90075-0.

Stockmans, F. 1933. Les Neuroptéridées des bassins houillers belges. (Première Partie). Mémoires du Musée royal d'Histoire naturelle de Belgique, 57, 1-61.

Stockmans, F. \& Willière, Y. 1952-1953. Végétaux namuriens de la Bélgique. Association pour l'Étude de la Paléontologie et de la Stratigraphie Houillères, 13. Texte (1953): 1-382; Atlas (1952): pls I-LVII.

Wagner, R.H. 1965. Stephanian B flora from the CiñeraMatallana coalfield (León) and neighbouring outliers. III: Callipteridium and Alethopteris. Notas y Comunicaciones del Instituto Geológico y Minero de España, 78, 5-70.

Wagner, R.H. 1983a. The palaeogeographical and age relationships of the Portuguese Carboniferous floras with those of other parts of the western Iberian Peninsula. In: The Carboniferous of Portugal (eds. Lemos de Sousa, M.J. \& Oliveira, J.T.). Memórias dos Serviços Geológicos de Portugal, 29, 153-177.

Wagner, R.H. 1983b. Neuropteris guadiatensis, a new species from the Westphalian B of the PeñarroyaBelmez Coalfield in the province of Córdoba, S.W. Spain. In: Contributions to the Carboniferous Geology and Palaeontology of the Iberian Peninsula (ed. Lemos de Sousa, M.J.). Universidade do Porto, Faculdade de Ciências, Mineralogia e Geologia, 93-99.

Wagner, R.H. 1984. Megafloral Zones of the Carboniferous. Compte Rendu 9e Congrès International de Stratigraphie et de Géologie du Carbonifêre, Washington and ChampaignUrbana 1979, 2, 109-134.

Wagner, R.H. 1999. Peñarroya, a strike-slip controlled basin of early Westphalian age in Southwest Spain. Vestnik Ceského geologického ústavu, 74 (2), 3-23.

Wagner, R.H. 2001. Fósiles vegetales. Recursos Naturales de Córdoba, 6, 1-105. Diputación de Córdoba, Departamento de Medio Ambiente y Protección Civil.

Wagner, R.H. 2004. The Iberian Massif: a Carboniferous assembly. Journal of Iberian Geology, 30, 93-108.

Wagner, R.H. 2013. El significado geológico de las cuencas carboníferas con flora fósil en Sierra Morena. In: Libro de resúmenes (eds. Álvarez-Vázquez, C. \& López Rodríguez, I.). XXIX Jornadas de Paleontología, Córdoba, 41-56. 
Wagner, R.H. \& Álvarez-Vázquez, C. 2010. The Carboniferous floras of the Iberian Peninsula: A synthesis with geological connotations. Review of Palaeobotany and Palynology, 162 (3), 238-324; doi:10.1016/j.revpalbo.2010.06.005.

Wagner, R.H. \& Winkler Prins, C.F. 2016. History and current status of the Pennsylvanian chronostratigraphic units: problems of definition and interregional correlation. Newsletters on Stratigraphy, 49/2, 281-320; doi: 10.1127/ nos/2016/0073.

Wagner, R.H., Coquel, R., Gabaldón, V., Robledo, J., Quesada, C., Hernández, J. \& Rodríguez, P. 1983. The Westphalian B of the Peñarroya-Belmez-Espiel Coalfield. In: Carboniferous Geology of the Sierra Morena. Field Trip D (eds. Quesada, C. \& Garrote Ruíz, A.). X Congrès International de Stratigraphie et de Géologie du Carbonifère, Madrid 1983, E.N. Adaro de Investigaciones Mineras, 53-64.
Weiss, Ch.E. 1869-1872. Fossile Flora der jüngsten Steinkohlenformation und des Rothliegenden im SaarRhein-Gebiete. Verlag von A. Henry, Bonn, 1-250.

Wendel, R. 1980. Callipteridium pteridium (Schlotheim) Zeiller im Typusgebiet des Saaletrogs. Schriftenreihe für geologische Wissenschaften, 16, 107-169.

White, D. 1900. The Stratigraphic Succession of the Fossil Floras of the Pottsville Formation in the Southern Anthracite Coal Field. Pennsylvania. Twentieth Annual Report, U.S. Geological Survey, II, 749-918.

Zalessky, M.D. 1907. Beiträge zur Kenntnis der fossilen Flora des Steinkohlenreviers von Dombrowa. Mémoires $d u$ Comité Géologique, Nouvelle Série, 33, 1-68 (in Russian and German). 